\title{
FACTORS AFFECTING THE SATISFACTION OF BANGLADESHI MEDICAL TOURISTS
}

\author{
Munira SULTANA* \\ Jagannath University, Department of Economics, Dhaka, Bangladesh, e-mail: luna_1442@yahoo.com
}

\begin{abstract}
Citation: Sultana, M. (2021). FACTORS AFFECTING THE SATISFACTION OF BANGLADESHI MEDICAL TOURISTS. GeoJournal of Tourism and Geosites, 38(4), 1125-1134. https://doi.org/10.30892/gtg.38418-752
\end{abstract}

\begin{abstract}
Medical tourism is a promising industry which is growing day by day. Researching on medical tourism is getting popularity in tourism literature. The aim of this study is to analyze the factors that have effects on medical tourist satisfaction towards medical tourism and also measure the satisfaction level. Thus, non-probability sampling method, especially convenience and snowball sampling technique were used to collect data from the respondents. Statistical analysis like factor analysis, descriptive analysis, and ordinal logistic regression analysis has been used to analyze the data collected through questionnaire. The statistical outcome indicates that doctors' and nurses' service quality, treatment facilities, cost of medical care, envi ronment of hospital, tourism facilities, availability of doctors and staffs were found to have an impact on the patients' satisfaction ratings. Patient demographic characteristics such as sex of the patients, age, and income had insignificant associations with satisfaction.
\end{abstract}

Key words: Factors, Bangladeshi Medical Tourists, Satisfaction, Medical Tourism

\section{INTRODUCTION}

Medical tourism, a form of tourism operation in which patients fly outside of their home country for medical care, has been increasing in popularity over the last few decades. This scenario accelerated the industry's growth; in 2017, the industry produced more than US\$ 82.27 billion globally (Medgadget, 2021). Medical tourism provides opportunities to the patients to access medical facilities not obtainable or affordable in their own countries (Synder et al., 2015; Crooks et al., 2010). Patients traveling as medical tourists from Bangladesh to renowned medical tourism destinations and hospitals overseas for medical treatment/surgery (Andaleeb et al., 2007). Medical tourism from Bangladesh is expanding exponentially day after day. In 2020, about 54 percent of Bangladeshi medical tourists have travelled India for medical travel (The Business Standard, 24.06.2021). Bangladesh has achieved huge progress in the health sector. Health infrastructures have undeniably increased in number of medical schools, medical universities, private medical colleges, private clinics, private hospitals, district hospitals, rural health centers and community clinics, as well as NGOs that play an important role in providing health care (Health Bulletin, 2018). In the recent years health care facilities and services of Bangladesh are not client focused, need based, and expansive to the majority of the people.

Therefore, Bangladeshi patients' who are not only the wealthy and the middle-class, but also the poor to travel crossborder to India, Thailand, and Singapore for higher perceived quality of medical treatment. Asian countries such as India, Thailand, Singapore, Malaysia and Indonesia has become famous to the Bangladeshi patients to travel for medical purposes while these countries are also exporting their healthcare facilities with the help of globalization (Ali and Medhekar, 2018; Bookman and Bookman, 2007). The affordability of these countries along with other facilities like quality medical service at lesser price, use of modern technologies in service provision, Joint Commission International (JCI) accredited medical facilities and professionals give them advantage to attract foreign patients into these countries (Ali and Medhekar, 2016). The survey finding where most people seek heart related, cancer, neurological and other critical treatments in foreign hospitals, especially India, due to the latter's competitive prices, quality treatment, communication understanding and geographic proximity (MacKain, 2003).

Among the destinations, Apollo Hospital in India, Mt. Elizabeth in Singapore and Bumrungrad in Thailand take the top three positions respectively of most popular healthcare provider. This is unsurprising, considering that Apollo is India's first corporate hospital and aims to spend Rs. 2,000 crores in the building of 15 new buildings, while Bumrungrad treats approximately 430,000 medical tourists from 190 different countries each year (Herrick, 2007).

Singapore has become a hub for international patients for wide varieties of medical services such as health screenings, high end surgeries (neurology, cardiology, ophthalmology, organ transplants) and generating good amount of earnings. The country holds many advantages which include well trained doctor from abroad, internationally accredited hospitals, and well developed infrastructure, robust medical ecosystem, free of political unrest situation, social stability, and innovative medical technology to draw the attention of potential medical tourists to travel Singapore (The Straits Times, 2015). Satisfaction can be treated as a vital aspect of quality and a key indicator of success in medical tourism. It is important because it increases competition among health service providers (Heydari et al., 2019).

The key role of outbound medical patients' satisfaction is depending on the assessment of their pre-travel hopes, images and perception about the destination and their post-travel experiences and understandings at this destination. If

\footnotetext{
* Corresponding author
} 
the real performance is better than patients' hopes, this leads to high satisfaction and if the real performance is poorer than their hopes, this leads to high dissatisfaction destination (Chon, 1989; Chen and Chen, 2010).

Previous literatures on medical tourism have indicated that there is a lack of comprehensive study that provides the information regarding outbound medical tourists' satisfaction in developing country like Bangladesh (Biswas et al., 2020). In particular, very little is known about the factors that influence outbound medical tourism and the satisfaction level of outbound medical tourist. To fill this gap, this study has been undertaken.

This paper is prepared as follows. After the introduction the literature review in Section 2 briefly mentions the factors that influence the satisfaction of medical tourist. Section three presents the research methodologies that are used. Result of exploratory factor analysis, regression analysis and descriptive statistics are presented in Section 4. Final section covers recommendation and conclusion Section 5, followed by future research and limitations in Section 6.

\section{LITERATURE REVIEW}

In the age of globalization with the help of market liberalization such as insurance, increased patient mobility due to greater ease of transportation and technological development along with the participation of the private sector in health care has increased medical tourism (Ratnasari et al., 2021). At the time of globalization, medical tourism is the practice of travelling beyond national borders in order to get private medical treatment and care.

Travel in a foreign country for medical treatment is increasing fast from the last decade because better medical services, know-how and proficiency in destination countries, ease mode of travel, specialized travel agent for medical care tourism and internet promotion played an important role in medical tourist travelling from developed or developing countries or which are prominent for medical care (Hadian et al., 2021; Stanley, 2010).

\section{Factors Affecting the Satisfaction of Bangladeshi Medical Tourists'}

When the performance of medical treatment is not satisfactory in-home country (Bangladesh) (Biswas et al., 2020). Then the patients take the decision to go abroad (India, Singapore or Thailand) for medical treatment. On the other hand, selection of medical tourism destinations is affected by the factors such as doctors' quality of medical care, cost of medical care, treatment facilities, environmental aspects, tourism facilities, service of medical staff and availability of doctors and staff. Each of these factors includes multiple issues (Hasan et al., 2020). Growing demand for medical tourism in Bangladesh is linked with medical patients' satisfaction. Medical patients' satisfaction influences the selection of medical tourism destinations. The Literature review includes certain factors that influence patients' satisfaction towards medical tourism. The descriptions of the key factors affecting medical tourists' satisfaction are given below:

\section{Quality of Medical Care}

The overall service quality of doctors in health care industry is a vital area for fascinating customer. It can be considered as one of the crucial factors that affect patients' satisfaction (Chen et al., 2016). If a physician provides good quality care to the patient, the patient satisfaction level increases (Chen et al., 2016; Celik et al., 2014). Doctors' reliability personified doctors who appropriately understand and explain laboratory reports, identify the disease proficiently, provide right clarifications to queries, evidence-based guidelines as well as generate a sense of safety (Andaleeb et al., 2007). Bikker and Thompson, (2006) emphasize relational skills as a significant factor on patient satisfaction Bikker and Thompson (2006) emphasize relational skills as a significant factor on patient satisfaction. Doctors' empathy denotes to the understanding of patients' physical and mental problems. Patients want doctors to be more concentrating, deliver personal care, and give mental support that may affect patients' satisfaction (Andaleeb et al., 2007).

\section{Cost of Medical care}

One of the vital determinants of customer satisfaction of any product or service is the cost. Moreover, cost of any product or service determines the competitiveness of that particular product or service in any field. It can consist of product cost, carriage cost, physical cost, social cost and opportunity cost. (Oliver, 1997; Hart, 2007; Luo and Homeburg, 2007). The cost of medical tourism is measured as one of the crucial factors (Cortez, 2008). It also significantly influences the patients' satisfaction (Chen et al., 2016).

\section{Treatment Facilities}

According to Hancock (2006) some of the core medical processes in the medical tourism arena such as cardiac surgery, cosmetic surgery, dental surgery, eye surgery, fertility treatment, orthopedic surgery and transplant surgery. Medical tourism does not comprise any kind of specific treatment but also added a wide range of treatment facilities (Mattoo and Rathindran, 2006). Paffhausen et al., (2010) not, medical tourism includes a wide variety of therapeutic treatments extending from numerous important treatments to different kinds of traditional and alternative treatments.

\section{Environment of the Hospital}

Patient satisfaction upsurges the image of hospital as well as market value, satisfied patients' elasticities the positive feedback, which is very much helpful for the medical care providers on a long-term basis (Zeithmal and Bitner, 2008). A research by Andaleeb (1998) states that cost of medical care's with quality facilities is significant in-patient satisfaction. If the physical facilities in the hospital such as Operation Theater, medical equipment, cabin, bed, floor, toilet and bathroom are neat and clean, it stretches a good feeling and the patient satisfaction can be increased. In case of assessment of hospital 
environment, typically encompasses physical entrance inside and outside of the hospitals. An appropriate and contented environment will intensification inpatient satisfaction (Kavadas et al., 2004).

\section{Tourism Facilities}

Tourism facilities can play a vital role behind medical tourists' satisfaction and selection of a particular destination for medical tourism. A possible medical tourist takes a decision to travel on the basis of a country's tourism attractions, protection and exclusive JCI-accredited hospitals. This may comprise tourism opportunities, security in travel, lodging, patented hospital, accredited hospitals, understanding with the local language and the English language facility and culture (Abubakar and Ilkan, 2016; Esiyok et al., 2016; Gill and Singh, 2011; Sultana et al., 2014).

According to (Smith and Puczko, 2009), medical tourists have a large impact on the tourism industry not only by being consumers of healthcare services but also by travelling to the destination, staying in different hotels and using tourism services. Moreover, Mamun and Andaleeb (2013) stated that countless services in hospitals such as pharmacies near hospitals, proper management of all schedules to avoid misbehavior, and investigative patients' history whereas serving international patients. Moreover, hotels and restaurants of international customary near hospitals, airports pickup and drop-up services need to be upgraded to attract more medical tourists from abroad. In addition, the destination should be culturally, politically, socially, and environmentally sound and friendly.

\section{Service of Medical Staff}

Medical staff showing politeness, helpfulness, and having a positive behavior towards patients, will have a profound impact on patients' satisfaction and as a result benefit healthcare provider (Andaleeb, 1998). The research in Pennsylvania indicates that vital attributes emphasized by patients for satisfaction include communication, staff proficiency, staff attitude, quality facilities, and perceived costs (Andaleeb, 1998). According to Babic-Banaszak et al. (2001) in Croatia, an effective response towards nurses' kindness, patience, willingness to help, compassion and time management are important to patients. Medical staff politeness, helpfulness, and positive behavior concerning patients will have a thoughtful impact on patients' satisfaction and benefit healthcare providers (Andaleeb, 1998; Musa et al., 2012).

\section{Availability (Doctor/Medical staff}

Availability is the probability that a system will be available to perform its function when called upon. Availability of various medical services largely depends on the availability of medical personnel. Lack of adequate medical personnel can adversely affect the availability of various medical services which in turn affects patients' satisfaction. It is moderately natural that everyone seeking medical treatment overseas imagines the quality of service. The most vital factor of all is receiving round the clock like better care, availability and accessibility of experienced doctors, medical staffs personalized care, availability of bed/ cabin and visa processing (Andaleeb et al., 2007; Drinkert, 2015; Siddiqui and Khandakar, 2007).

\section{METHODS}

The study mainly uses primary data obtained through interviewing outbound medical tourists. The patients who travelled to India, Singapore and Thailand for treatment purpose were interviewed. There is no data base or list of outbound medical tourists in Bangladesh. Thus, non-probability sampling method, especially convenience and snowball sampling technique were used to collect data from the respondents. The primary source of information regarding the respondents was found from friends, relatives, colleagues and medical agents. Based on the primary information we traced the outbound medical tourists over a 3 months period. Due to resource constraint, we restricted to interview limited number of respondents. We made a list of 150 patients who travelled to each of the three countries (India, Thailand and Singapore) during June 2017 -June 2018. The interview was continued for each country until reaching to 100 respondents. Thus, a total of 300 outbound medical tourists were interviewed from three countries. Semi-structured questionnaire was prepared. The questions include open-ended questions, close-ended questions, multiple-choice questions and questions based on five-point Likert scale from strongly agree (5) to strongly disagree (1) or from very much dissatisfied (1) to very much satisfied (5). The reliability test of the Likert scale in question was made and found reliable with high Cronbach's alpha (with most of them above 0.9). Descriptive statistics, factor analysis, MannWhitneyU test and Kruskal -Wallis H test, Ordinal logistic regression analysis conducted to analyze the data.

\section{FINDINGS AND ANALYSIS}

\section{Demographic Features of the Respondents}

Of the total respondents 300 in the survey, 61 percent were male while 39 percent were female. Of the respondents, most of the patients selected Singapore and Thailand (50\% and 51\% respectively) as the medical tourism destinations that had monthly family incomes above 100000 BDT. Moreover, 52\% of the patients have selected India for medical treatment and their monthly income was 50001 t0 100000 .Of the patients (84\%) were the group of 16 to 55 years. The highest frequency of the patients $(30.66 \%)$ belonged to the group of businessmen among the three countries $(30 \%, 28 \%$ and $34 \%$ respectively) followed by the private employees $(24.66 \%)$.

\section{Medical Tour related Information of Respondents \\ Purpose of Visit}

The distribution of the purposes of visit is shown in AppendixA-1. More than (85\%) patients travel for medical 
treatment purpose and very few of patients (6\%) travel for vacation and other purpose. So, it is clear that the patients' main purpose for visiting abroad was to obtain medical treatment.

\section{Sources of Medical Treatment Information}

It is seen from the Appendix A- 2 that more than half of the respondents (59.34\%) found information about the hospitals from the reference of old patients, family and relatives. It is also illustrating that doctors from home country reference was also significant source of information (14\%). But a few respondents' $(12 \%)$ got the information from their friends. It is clear from the table that those patients who were willing to seek their medical treatment in abroad not always derived by their own decision, there were some key players motivating them to take foreign health care facilities.

\section{Types of Diseases of the Medical Tourists}

The distribution of the types of diseases of the medical tourists is shown in A-3. This study shows that, mainly people took foreign medical services for Cardiovascular disease $(16.33 \%)$. The next important item performed outside was Orthopedic (11\%), cancer $(10.99 \%)$. Liver (9\%) and Neurology $(8.9 \%)$. The other treatments include Gastroenterology, Urology, ENT, General surgery, Comprehensive medical check-up, Gynecology and Dental.

\section{Reasons for Going Abroad for Taking Medical Treatment}

In this study, 11 items were evaluated to identify the reasons for going abroad for taking medical treatment. The mean scores of the 11 items of respondents are presented in the following Table 1 . The overall analysis of medical tourists suggests that the highest rated item and the strongest influential variable for going abroad was "Insufficient consultation time by the doctors followed by lack of confidence on medical care in Bangladesh, and the dissatisfaction about quality of medical care.

\section{Factors associated with Satisfaction level of Medical Tourists}

\section{Satisfaction Level of Medical Tourist in terms of Gender}

The difference in the satisfaction level of outbound medical tourist in terms of gender Mann-Whitney U Test was used. The results indicate that the level of significance for the satisfaction of outbound medical tourist in terms of gender amounts more than $5 \%$, respectively $\mathrm{p}=0.923$, which means that with the reliability of $95 \%$ it can be concluded that there was no statistically significant difference for the satisfaction of outbound medical tourist considering the gender of the respondents.Satisfaction Level of Medical Tourist in terms of Age. The differences in the satisfaction level of outbound medical tourist were explored in terms of age using Kruskal-Wallis test.

Table 1. Mean Scores of the 11 variables of the respondents' (overall analysis)

\begin{tabular}{|l|c|c|c|}
\hline Variables & Mean & SD & Rank \\
\hline Insufficient consultation time by the doctors & 4.21 & .734 & $1^{\text {st }}$ \\
\hline Lack of confidence on medical care & 4.19 & .634 & $2^{\text {nd }}$ \\
\hline Dissatisfaction about quality of medical care & 4.16 & .506 & $3^{\text {rd }}$ \\
\hline Poor diagnosis facilities & 4.14 & .634 & $4^{\text {th }}$ \\
\hline High cost of medical care & 4.11 & .679 & $5^{\text {th }}$ \\
\hline Long Waiting time & 4.05 & .563 & $6^{\text {th }}$ \\
\hline Inadequate treatment facilities & 4.03 & .451 & $7^{\text {th }}$ \\
\hline Non-curability & 4.02 & .935 & $8^{\text {th }}$ \\
\hline Lack of experienced doctor & 3.88 & .609 & $9^{\text {th }}$ \\
\hline Nearness & 2.75 & .449 & $10^{\text {th }}$ \\
\hline Language and culture & 2.65 & .506 & $11^{\text {th }}$ \\
\hline
\end{tabular}

Table 2. Results of Mann-Whitney U Test in terms of Gender

\begin{tabular}{|c|c|c|c|}
\hline Group & $\mathrm{N}$ & Mean Rank & P-value \\
\hline Male & 184 & 55.63 & Mann-Whitney \\
Female & 116 & 78.20 & $\mathrm{U}=1234.000 \quad \mathrm{P}=0.923$ \\
\hline
\end{tabular}

Table 3. Results of the Kruskal-Wallis Test in terms of age

\begin{tabular}{|c|c|c|c|}
\hline Age Group & $\mathrm{N}$ & Mean Rank & P-value \\
\hline Below 15 years & 15 & 30.45 & \multirow{6}{*}{$\begin{array}{c}\chi^{2}=1.227 \\
p=0.120\end{array}$} \\
\hline $16-25$ years & 64 & 88.12 & \\
\hline 26-35 years & 71 & 85.30 & \\
\hline $36-45$ years & 67 & 76.12 & \\
\hline $46-55$ years & 49 & 63.34 & \\
\hline Above 56 years & 34 & 51.90 & \\
\hline Total & & & \\
\hline
\end{tabular}

The results indicate that the level of significance for the satisfaction of outbound medical tourist in terms of age amounts more than $5 \%$, respectively $\mathrm{p}=0.120$, which means that with the reliability of $95 \%$ it can be concluded that there was no statistically significant difference for the satisfaction of outbound medical tourist considering the age of the respondents. Satisfaction Level of Medical Tourist in terms of Educational Qualification. The results indicate that the level of significance for the satisfaction of outbound medical tourist in terms of educational qualification amounts more than 5\%, respectively $\mathrm{p}=0.827$, which means that with the reliability of $95 \%$ it can be concluded that there was no statistically significant difference for the satisfaction of outbound medical tourist considering the educational qualification of the respondents.

\section{Factor Analysis'}

Exploratory Factor analysis was conducted to identify most important factors that affecting outbound medical tourists' satisfaction from the 300 sample medical patients regarding 36 variables which account for their iner-correlation. A Principal Factor Analysis with an orthogonal rotation (Varimax) using the statistical package was performed on the survey data to identify the factors. Seven factors were derived from this analysis. These seven factors had explained $79.07 \%$ variability of the data. The factor analysis of 36 variables with 300 sample was found adequate (KMO test result $=0.8 \geq 0.5)$ and valid (Bartlett's test of sphericity indicates a significance level of 0.000 ).
Table 4. Results of the Kruskal-Wallis

Test in terms of Educational Qualification

\begin{tabular}{|c|c|c|c|}
\hline Educational Qualification & $\mathrm{N}$ & Mean Rank & P-value \\
\hline Primary education & 10 & 25.12 & \multirow{2}{*}{} \\
\cline { 1 - 3 } SSC & 26 & 43.31 & $\chi 21.342$ \\
p $=0.827$ \\
\hline HSC & 76 & 90.67 & \\
\hline University level & 188 & 99.90 & \\
\hline
\end{tabular}


Since the positive factor loading value of 0.5 or greater was considered as significant in factor analysis. The communalities of the variables were found strong which indicates vigorous relationships among the variables. The Cronbach's Alpha coefficient 0.9 or higher indicating items internally consistent and shows good relation among the variables. The factor analysis showed that to mitigate outbound medical tourism from Bangladesh, we need to focus on the following seven factors with Eigen value greater than one. Results of the factor analysis of seven factors are presented below.

\section{Quality of Medical Care}

The first principal factor was Quality of Medical Care mainly related to doctors' reliability, skill, empathy and interpersonal communication with patients. It is seen from the Table 6 the variable explained 23\% of the variability. High variance $(23 \%)$ of this factor indicates there was a strong association between doctors' quality of medical care and underlying following variables. The strong correlation among the variables indicates doctors' quality of medical care.

Table 5. Results from Factor Analysis- Quality of Medical Care

\begin{tabular}{|l|c|c|}
\hline \multicolumn{1}{|c|}{ Variables } & Factor Loadings & Communalities \\
\hline Doctors visited in abroad have heard and understood symptom of your disease & .821 & .740 \\
\hline Doctors visited in abroad have answered all the questions related to your disease & .705 & .825 \\
\hline Doctors visited in abroad have examined you with care & .965 & .683 \\
\hline Doctors visited in abroad have informed you the process of treatment in details & .939 & .833 \\
\hline Doctors visited in abroad have advised you on the basis of your disease's symptom & .844 & .747 \\
\hline Doctors visited in abroad have clarified you the reasons for giving pathological test & .821 & .798 \\
\hline Doctors visited in abroad are careful and sincere to their patients & .751 & .625 \\
\hline Doctors visited in abroad keep confidentiality during medical treatment & .907 & .894 \\
\hline Doctors visited in abroad are capable of identifying your problems & .948 & .800 \\
\hline Doctors visited in abroad have provided you right medical treatment & .836 & .736 \\
\hline
\end{tabular}

$($ Kaiser-Meyer-Olkin $=.824$, Bartlett's Test of Sphericity Sig $=.000$, Variance explained $=23 \%$, Cronbach's Alpha .908 , Eigen value $=4.167$

\section{Treatment Facilities}

The second principal factor was Treatment Facilities mainly consists of reputation of medical care/ doctors and staffs, equipment and diagnosis facilities, and wide range of treatment facilities. Table 7 shows that the variable explained $16.24 \%$ of the variability. High variance $(16.24 \%)$ of this factor indicates that there was a strong association between treatment facilities and its underlying variables. Positive factor loading signify that treatment facilities positively correlated with availability of medical equipment, accurate diagnosis of diseases, world standard medical facilities, availability of treatment and reputation of medical staff. Therefore, the underlying dimension of the following variables prove that treatment facilities were highly involved with patient satisfaction.

Table 6. Results from Factor Analysis- Treatment Facilities

\begin{tabular}{|l|c|c|}
\hline \multicolumn{1}{|c|}{ Variables } & Factor Loadings & Communalities \\
\hline $\begin{array}{l}\text { There is an opportunity for medical treatment } \\
\text { of all kinds of disease in abroad }\end{array}$ & .834 & .728 \\
\hline $\begin{array}{l}\text { Recognized/International accredited hospital } \\
\text { / positive reputation of medical facility }\end{array}$ & .868 & .774 \\
\hline $\begin{array}{l}\text { The quality of disease diagnosis is high } \\
\text { because of using advanced technology in } \\
\text { abroad }\end{array}$ & .961 & .844 \\
\hline $\begin{array}{l}\text { Positive reputation of Physicians and } \\
\text { medical staffs in abroad }\end{array}$ & .854 & .702 \\
\hline $\begin{array}{l}\text { Advanced medical equipment is available in } \\
\text { the hospitals of abroad }\end{array}$ & .922 & .839 \\
\hline
\end{tabular}

(Kaiser-Meyer-Olkin $=.909$, Bartlett's Test of Sphericity Sig $=.000$, Variance explained $=16.24 \%$, Cronbach's Alpha .902 , Eigen value $=3.207$
Table 7. Results from Factor Analysis- Cost of Medical Care

\begin{tabular}{|c|c|c|}
\hline Variables & $\begin{array}{c}\text { Factor } \\
\text { Loadings }\end{array}$ & Communalities \\
\hline $\begin{array}{c}\text { Doctors' fee in abroad } \\
\text { are cost-effective }\end{array}$ & .939 & .731 \\
\hline $\begin{array}{c}\text { Diagnostics fee in } \\
\text { abroad are cost-effective }\end{array}$ & .938 & .852 \\
\hline $\begin{array}{c}\text { Transportation fare in } \\
\text { abroad are cost effective }\end{array}$ & .876 & .733 \\
\hline $\begin{array}{c}\text { Medicine cost in } \\
\text { abroad is low }\end{array}$ & .822 & .872 \\
\hline
\end{tabular}

(Kaiser-Meyer-Olkin $=.834$, Bartlett's Test of Sphericity $\mathrm{Sig}=.000$, Variance explained $=11.33 \%$, Cronbach's Alpha .911, Eigenvalue $=2.23$

\section{Cost of Medical Care}

Cost of medical care was the third factor includes doctors' fee, diagnostic fee, medicine cost, and transportation cost. Table 8 shows that the factor explains $11.33 \%$ of the variability. High variance $(16.24 \%)$ of this factor indicates that there was a strong association between cost of medical care and underlying variables. The strong correlation among the variables indicates cost of medical care. Positive factor loading signify that the cost of medical care closely correlated with consultation fee of doctors, price of diagnosis test, medicine cost, transportation fare. Therefore, the underlying dimensions of the following variables prove that cost of medical care was highly involved with patient satisfaction.

\section{Environment of the Hospital}

The fourth principal factor was Environmental aspects mainly related to cleanliness of the physical facilities and clam environment of the hospital. Table 9 shows that this factor explains almost $9.75 \%$ of the variance. Positive factor loading signify that environment of the hospital closely correlated with cleanliness of hospital physical facilities and clam environment. Therefore, the underlying dimension of the following variables prove that environment of the hospitals was highly involved with patient satisfaction. 
Table 8. Results from Factor Analysis- Environmental Aspects

\begin{tabular}{|l|c|c|}
\hline \multicolumn{1}{|c|}{ Items } & $\begin{array}{c}\text { Factor } \\
\text { Loadings }\end{array}$ & Communalities \\
\hline Hospitals in abroad are attractive & .875 & .729 \\
\hline $\begin{array}{l}\text { Cabin, bed and floor of hospitals in } \\
\text { abroad are clean }\end{array}$ & .923 & .853 \\
\hline $\begin{array}{l}\text { Toilet and bathroom of hospitals in } \\
\text { abroad are clean }\end{array}$ & .818 & .722 \\
\hline $\begin{array}{l}\text { Operation theater and medical equipment } \\
\text { of hospitals in abroad are clean }\end{array}$ & .944 & .862 \\
\hline
\end{tabular}

(Kaiser-Meyer-Olkin $=.915$, Bartlett's Test of Sphericity Sig $=.000$, Variance explained $=9.75 \%$, Cronbach's Alpha .928 , Eigen Value $=1.525$
Table 9. Results from Factor Analysis- Service of Medical Staff

\begin{tabular}{|l|c|c|}
\hline \multicolumn{1}{|c|}{ Items } & $\begin{array}{c}\text { Factor } \\
\text { Loadings }\end{array}$ & Communalities \\
\hline $\begin{array}{l}\text { Medical staff in abroad are always } \\
\text { ready to fulfill the need of patients }\end{array}$ & .912 & .847 \\
\hline $\begin{array}{l}\text { Medical staff in abroad are gentle and } \\
\text { sincere }\end{array}$ & .745 & .626 \\
\hline $\begin{array}{l}\text { Medical staff are responsible about } \\
\text { their duties }\end{array}$ & .892 & .733 \\
\hline Medical staff performs their duties timely & .765 & .643 \\
\hline
\end{tabular}

(Kaiser-Meyer-Olkin $=.867$, Bartlett's Test of Sphericity Sig $=.000$,

Variance explained $=7.25 \%$, Cronbach's Alpha .923, Eigen Value $=1.323$

\section{Service of Medical Staff (Nurse/ caregiver)}

Service of medical staff was the fifth principal factor mainly consists of patient centered, timely manner, courtesy, and sincerity of the medical staff in the foreign hospital. It is seen from the table 10 total 4 items are loaded under this factor explained almost $7.25 \%$ of the variance. Positive factor loading signify that service of medical staff closely correlated with staffs' courtesy, sincerity, responsibility and punctuality. The closely correlated variables indicate service of medical staff. Therefore, the underlying dimension of the following variables proves that service of medical staff was highly involved with patient satisfaction.

\section{Availability (Doctor/ Medical staff)}

Table 10 shows that the sixth factor Availability occupies $6.35 \%$ of total variance consist of three variables availability and accessibly of experienced doctor and staff. The positive factor loading signify that all variables positively correlated with each other. Therefore, the underlying dimension of the following variables prove that availability was highly involved with patient satisfaction.

\section{Tourism Facilities}

It is seen from the Table 11 shows that the seventh principal factor was tourism Facilities consists of attractive medical tourism destination, cheap accommodation and amicable hospitality account for $5.15 \%$ of the total variable. Positive factor loading signify that tourism facilities closely correlated with each variable. So, the underlying dimension of the following variables prove that availability was highly involved with patient satisfaction.

Table 10. Results from Factor Analysis- Availability

\begin{tabular}{|c|c|c|}
\hline Items & $\begin{array}{c}\text { Factor } \\
\text { Loadings }\end{array}$ & Communalities \\
\hline $\begin{array}{c}\text { Experienced doctor is } \\
\text { easily accessible }\end{array}$ & .963 & .722 \\
\hline Medical staff are available & .847 & .747 \\
\hline $\begin{array}{c}\text { Doctor follow up treatment } \\
\text { regularly }\end{array}$ & .856 & .721 \\
\hline
\end{tabular}

(Kaiser-Meyer-Olkin $=.895$, Bartlett's Test of Sphericity Sig

$=.000$, Variance explained $=6.35 \%$, Cronbach's Alpha .914 )
Table 11. Results from Factor Analysis- Tourism Facilities

\begin{tabular}{|l|c|c|}
\hline \multicolumn{1}{|c|}{ Items } & Factor Loadings & Communalities \\
\hline $\begin{array}{l}\text { Tourism facilities are available together } \\
\text { with medical treatment facilities in abroad }\end{array}$ & .846 & .731 \\
\hline Tourism spot are safe and secured in abroad & .981 & .877 \\
\hline Political stability prevails in abroad & .833 & .752 \\
Transportation is very easy in abroad & .959 & .859 \\
Accommodation is cheap in abroad & .840 & .732 \\
\hline Local people are friendly and sincere in abroad & .823 & .724 \\
\hline
\end{tabular}

(Kaiser-Meyer-Olkin $=.857$, Bartlett's Test of Sphericity Sig $=.000$,

Variance explained $=5.153 \%$, Cronbach's Alpha .937 , Eigen value $=1.406$

\section{Ordinal Logistic Regression Model:}

An ordinal logistic regression model was used to measure the impact of independent variables on the medical patients' satisfaction derived from the factor analysis. Considering the seven factors as independent variables $\left(x_{i}\right.$. for $\left.i=1-7\right)$ and establishing medical tourist's satisfaction as the dependent variable $(Y)$ that belongs to the ordinal in nature (ranging from Very much dissatisfied $=1$ to Very much satisfied $=5$ ). This analysis is useful to investigate the association between the predictors and the response variable.

The ordinal logistic model being fitted does not violate the parallel lines assumption. The likelihood ratio test for model $\chi 2=441.13, P<0.05$ indicated that the regression equations were significant. In other words, it indicates that as a minimum one of the regression coefficients included in the model is not equal to zero. The goodness-of-fit operation showed a good model fit through the following measures: Pearson $\chi 2=32664.90(P<0.05)$, Cox and Snell $R^{2}=0.73$, and Nagelkerke $R^{2}=$ 0.89 , where $Y$ is the medical tourist's satisfaction $(Y \leq j$, for $j=1-7)$. The values of $-7.32,-6.41,-6.26,-4.22,-3.43,-3.17$, 2.32 , are the estimated values of the constant terms $\left(\beta_{0 j}\right.$, for $\left.j=1-7\right)$ for each of the seven equations, respectively, which means that when all the independent variables are equal to $0, P(Y \leq j)=e^{\beta 0 j(I+e \beta 0 j)}$ Concerning the independent variables $\left(x_{\mathrm{i}}\right.$ for $i=1-7), x_{1}$ represents doctors' quality of medical care, $x_{2}$ represents cost of medical care, $x_{3}$ represents treatment facilities, $x_{4}$ represents environmental aspects, $x_{5}$ represents tourism facilities, $x_{6}$ represents service of medical staff, $x_{7}$ represents availability. Finally, seven regression equations (Chen et al., 2016) were established as:

$$
\begin{aligned}
& \text { Logit }(\mathrm{P})(\mathrm{Y} \leq 1)=-7.32+0.82 \mathrm{x}_{1}+1.19 \mathrm{x}_{2}+0.89 \mathrm{x}_{3}+1.29 \mathrm{x}_{4}+0.71 \mathrm{x}_{5}+1.28 \mathrm{x}_{6}-0.31 \mathrm{x}_{7} \\
& \operatorname{Logit}(\mathrm{P})(\mathrm{Y} \leq 2)=-6.41+0.82 \mathrm{x}_{1}+1.19 \mathrm{x}_{2}+0.89 \mathrm{x}_{3}+1.29 \mathrm{x}_{4}+0.71 \mathrm{x}_{5}+1.28 \mathrm{x}_{6}-0.31 \mathrm{x}_{7} \\
& \operatorname{Logit}(\mathrm{P})(\mathrm{Y} \leq 3)=-6.26+0.82 \mathrm{x}_{1}+1.19 \mathrm{x}_{2}+0.89 \mathrm{x}_{3}+1.29 \mathrm{x}_{4}+0.71 \mathrm{x}_{5}+1.28 \mathrm{x}_{6}-0.31 \mathrm{x}_{7}
\end{aligned}
$$


Logit $(\mathrm{P})(\mathrm{Y} \leq 4)=-4.22+0.82 \mathrm{x}_{1}+1.19 \mathrm{x}_{2}+0.89 \mathrm{x}_{3}+1.29 \mathrm{x}_{4}+0.71 \mathrm{x}_{5}+1.28 \mathrm{x}_{6}-0.31 \mathrm{x}_{7}$ Logit $(\mathrm{P})(\mathrm{Y} \leq 5)=-3.43+0.82 \mathrm{x}_{1}+1.19 \mathrm{x}_{2}+0.89 \mathrm{x}_{3}+1.29 \mathrm{x}_{4}+0.71 \mathrm{x}_{5}+1.28 \mathrm{x}_{6}-0.31 \mathrm{x}_{7}$ Logit $(\mathrm{P})(\mathrm{Y} \leq 6)=-3.17+0.82 \mathrm{x}_{1}+1.19 \mathrm{x}_{2}+0.89 \mathrm{x}_{3}+1.29 \mathrm{x}_{4}+0.71 \mathrm{x}_{5}+1.28 \mathrm{x}_{6}-0.31 \mathrm{x}_{7}$ Logit $(\mathrm{P})(\mathrm{Y} \leq 7)=-2.32+0.82 \mathrm{x}_{1}+1.19 \mathrm{x}_{2}+0.89 \mathrm{x}_{3}+1.29 \mathrm{x}_{4}+0.71 \mathrm{x}_{5}+1.28 \mathrm{x}_{6}-0.31 \mathrm{x}_{7}$

Table 12. Results of the Ordinal Regression Analysis

\begin{tabular}{|l|c|c|c|c|c|c|}
\hline \multirow{2}{*}{ Independent variables $(\mathrm{x})$} & \multicolumn{7}{|c|}{ Dependent Variable $(\mathrm{Y})$ OR } \\
\cline { 2 - 7 } & Estimate & SE & Wald $\mathbf{x}^{2}$ & P-value & OR & $(\mathbf{9 5 \%}$ CI) \\
\hline Doctors' quality of medical care $\left(\mathrm{x}_{1}\right)$ & 0.82 & 0.08 & 159.63 & 0.002 & 2.94 & $2.22-2.76$ \\
\hline Cost of medical care $\left(\mathrm{x}_{2}\right)$ & 1.19 & 0.07 & 129.21 & 0.005 & 2.26 & $2.92-3.15$ \\
\hline Treatment facilities $\left(\mathrm{x}_{3}\right)$ & 0.89 & 0.04 & 175.47 & 0.0032 & 2.30 & $2.38-2.92$ \\
\hline Environmental aspects $\left(\mathrm{x}_{4}\right)$ & 1.29 & 0.06 & 109.74 & 0.004 & 2.23 & $2.39-2.88$ \\
\hline Tourism facilities $\left(\mathrm{x}_{5}\right)$ & 0.71 & 0.07 & 98.55 & 0.006 & 1.30 & $1.40-2.02$ \\
\hline Service of medical staff $\left(\mathrm{x}_{6}\right)$ & 1.28 & 0.07 & 138.89 & 0.012 & 1.45 & $1.91-2.56$ \\
\hline Availability $\left(\mathrm{x}_{7}\right)$ & 0.87 & 0.08 & 113.09 & 0.0234 & 1.42 & $1.70-2.24$ \\
\hline
\end{tabular}

Notes: Estimate is the value of partial regression coefficients. Reference: medical tourist's satisfaction $=5$ (completely satisfied). Link function: logit; Abbreviations: $\mathrm{OR}=$ Odds Ratio; $\mathrm{SE}=$ Standard Error; $\mathrm{CI}=$ Confidence Interval.

Table 12 shows that the outcome of ordinal logistic analysis shows all seven independent predictors (Quality of medical care, Cost of medical care, Treatment facilities, Environmental aspects, Tourism facilities, Service of medical staff, and Availability (Doctor /Staff) had significant impacts $(\mathrm{P} \leq 0.05)$ on dependent variable, with odds ratios of 2.94, 2.30, 2.26, $2.23,1.45,1.42,1.30$ respectively. The interpretation of the results was accomplished based on the proportional odds ratios quality of medical care was the most significant variable of patient satisfaction with the largest odds ratio $(\mathrm{OR}=2.94 ; 95 \%$ $\mathrm{CI}=2.22-2.76, \mathrm{p}<.05)$. It implies that a unit increase in respondents' quality of care, 2.94 increase in the log-odds of being a higher satisfaction level given all of the other variables remain constant. Correspondingly, the patients were 2.30 times very much satisfied than other combined satisfaction levels, in terms of treatment facilities $(\mathrm{OR}=2.30 ; 95 \% \mathrm{CI}=$ $2.38-2.92, \mathrm{p}<.05)$ of the hospital. The estimation results showed that patients cost of medical care $(\mathrm{OR}=2.26 ; 95 \%$ $\mathrm{CI}=2.92-3.15 \mathrm{p}<.05)$ were 2.26 times very much satisfied compared to other satisfaction levels given the other variables were constant. However, Environmental aspects $(\mathrm{OR}=2.23 ; 95 \% \mathrm{CI}=2.39-2.88, \mathrm{p}<.05)$ were two times more very much satisfied. Service of medical staff $(\mathrm{OR}=1.45 ; 95 \% \mathrm{CI}=1.91-2.56, \mathrm{p}<.05$ were approximately one times more very much satisfied. Availability (Doctor/ Medical staff) increases the possibility of patient satisfaction $(\mathrm{OR}=1.42 ; 95 \%$ $\mathrm{CI}=1.70-2.24, \mathrm{p}<.05)$. Moreover, patients were $(\mathrm{OR}=1.30 ; 95 \% \mathrm{CI}=1.40-2.02, \mathrm{p}<.05)$ one times more very satisfied in visited countries tourism facilities. The regression analysis shows that in order to be more competitive. We need to emphasize on the significant seven factors with $(\mathrm{OR}>1 ; \mathrm{p}<.05)$.

\section{DISCUSSION ON KEY FINDINGS}

The study highlights the significance of quality of medical care in determining the medical tourists' satisfaction level. The quality medical care of doctor was a prominent factor for treatment. The criteria for assessing the quality care of doctors in this regard were professional excellence, skill and knowledge, empathy and interpersonal communication with patient. The more satisfied a patient is with doctors' quality of care, the overall satisfaction is more. Existing literature also found similar evidence by (Chen et al., 2016; Celik et al., 2014; Andaleeb et al., 2007; Tung and Chang, 2009; Collins et al., 2019). Majority of the patients visited abroad had shown their positivity about the health service provided by the doctor. According to the patients under the survey, the doctors were more professional, sincere and trustworthy to their work such as they had explained problems of the patient and gave information about their health-related issue.

The waiting time in abroad was considerable. Existing literature also found similar evidence by (Ali and Medhekar, 2018; Celik et al., 2014; Koermer and Kilbane, 2008). The policy makers should instigate continuous technical and behavioral training and an evaluation programmed for physicians. Besides, the government should provide scholarships to the practitioners to get higher medical education and expertise from abroad.

With that facility, doctors in Bangladesh can develop their academic standards and experience that will help to handle any complex case regarding patients' disease. At the same time, to satisfy the medical patients, the number of patients visited or supervised by a doctor in a day should be limited in both private and public hospital (Suppose 20-25 patient per physician daily) and fixing up amount of time to be spent for single patient.

The second prominent factor in abroad was treatment facilities mainly consist of reputation of medical care and staff, equipment facility, accurate diagnosis facilities and wide range of treatment facilities. In this study, the treatment facilities had been found to have a positive impact on patient satisfaction. Previous studies (Drinkert, 2015) had reported that treatment facilities were significantly associated with quality of service. Majority of the medical tourists under the survey stated that, hospitals in abroad were capable of handling any complex case of patients' disease because they had well trained medical staffs, highly experienced doctors studying in world class medical institutions and had advanced medical technology. Accurate diagnosis of disease was possible into short period of time due to use of up-to-date and modern medical technology and expertise. International accredited hospitals had ensured patient safety and quality of health care as well as creating opportunity for all kinds of treatment. Similar findings were reached by (Ali and Medhekar, 2018). Modern Diagnostic centers and international accredited hospital should be established so that local patient can receive better medical care in the home country. In the present time poor diagnosis facilities create dissatisfaction towards the medical service in Bangladesh. So, government should take action against the hospital by 
mobile court for using expired reagent in its laboratory and for selling unapproved drugs. In addition, modern and quality training should be arranged for doctors, staff in targeted areas such as diagnosis, pathological and radiological investigation and using of latest medical technology. Budgets need to be increased for specialized hospitals in medical field by purchasing required technology and surgical equipment. If the hospital provides satisfactory and effective quality facilities such as well -resourced laboratory, surgical equipment, experienced manpower, and good communication according to patients' expectation, then patient will be reluctant to go abroad.

Cost of medical care consists of doctor's fee, diagnostic cost, hospital cost, transportation fare and it was also significantly influenced patients' satisfaction. Similar findings were found by the existing literature (Chen et al., 2016; Sultana et al., 2014; Drinkert, 2015). Andaleeb et al., (2007) found that cost of medical care was insignificant to patient satisfaction. Majority of the patients under the survey states that in abroad treatment cost of private healthcare services came out to be more cost effective (price and quality balance) than private healthcare services in Bangladesh. Easy transportation, essential diagnostic test, reasonable fee for expertise, transparency in medical treatment cost and bills in foreign hospital reduces extra cost of patients which also increased patient satisfaction. The findings of the study indicate that most of the patients had taken treatment in private hospital in Bangladesh. The existing medical practices among the private medical service providers charge high price on limited quality care. Besides, the patients in Bangladesh not getting good quality service by spending more money. Government should take appropriate measures by monitoring the prices of private hospital as well as fix the charges of services provided by private hospitals and health clinic.

The environment of hospital leaves a positive impact on patient satisfaction. Similar conclusions were reached by the existing literature (Abdellah et al., 1986; Siddiqui and Khandaker, 2007a; Chen et al., 2016) concerning environmental aspects and patient satisfaction. The hospital environment usually comprises physical facilities inside the hospitals (such as Operation Theater, medical equipment, cabin, bed, floor, toilet and bathroom). All hospitals and diagnostic centers in the country should take the active measurement for the better development of the overall environment. Similar to doctor's quality, service of medical staff plays a major role in patients' satisfaction. Service of medical staffs can greatly affect patient satisfaction. Previous studies (Chen et al., 2016; Andaleeb et al., 2007) found that services of medical staff were significantly associated with patients' satisfaction. Bangladeshi patients found that medical staffs' in abroad were gentle, sincere and dedicated to the patients. So, the patients who got treatment from abroad had higher level of satisfaction. Professional training should be needed in the field of patient safety, patient care and clinical efficiency for the medical staff. To meet the patient's needs and improve nurses' services, health departments in the home country should deliver better medical packages, higher salaries, equipment accessibility, and stringent supervision.

The present study has also emphasized the significance of availability of experienced doctors and medical staffs in determining the medical tourists' satisfaction level. The more satisfied a patient is with availability of doctor and staff, the overall satisfaction is more. Similar evidence is also found in other studies (Drinkert, 2015; Siddiqui and Khandaker, 2007a). According to the patients under the survey in abroad experienced doctors and medical staff were accessible at any time when patient required, and doctors follow up inpatient regularly.

\section{RECOMMENDATIONS AND CONCLUSION}

A set of recommendations, based on the key findings, has been put forward so that government can take necessary measures to reduce outbound medical tourism from Bangladesh through improving the health system of the country. The policy makers should instigate continuous technical and behavioral training and an evaluation programmed for physicians. Besides, the government should provide scholarships to the practitioners to get higher medical education and expertise from abroad. With that facility, doctors in Bangladesh can develop their academic standards and experience that will help to handle any complex case regarding patients' disease. At the same time, to satisfy the medical patients, the number of patients visited or supervised by a doctor in a day should be limited in both private and public hospital (Suppose 20-25 patient per physician daily) and fixing up amount of time to be spent for single patient.

Modern Diagnostic centers and international accredited hospital should be established so that local patient can receive better medical care in the home country. In the present time poor diagnosis facilities create dissatisfaction towards the medical service in Bangladesh. So, government should take action against the hospital by mobile court for using expired reagent in its laboratory and for selling unapproved drugs. In addition, modern and quality training should be arranged for doctors, staff in targeted areas such as diagnosis, pathological and radiological investigation and using of latest medical technology. Budgets need to be increased for specialized hospitals in medical field by purchasing required technology and surgical equipment. If the hospital provides satisfactory and effective quality facilities such as well resourced laboratory, surgical equipment, experienced manpower, and good communication according to patients' expectation, then patient will be reluctant to go abroad. The findings of the study indicate that most of the patients had taken treatment in private hospital in Bangladesh. The existing medical practices among the private medical service providers charge high price on limited quality care. Besides, the patients in Bangladesh not getting good quality service by spending more money. Government should take appropriate measures by monitoring the prices of private hospital as well as fix the charges of services provided by private hospitals and health clinic.

All hospitals and diagnostic centers in the country should take the active measurement for the better development of the overall environment. However, these comprehensive systems need public and private cooperation and management. There is a severe problem of ineffectual medical staff in Bangladesh. For that reason, professional training should be needed in the field of patient safety, patient care and clinical efficiency for the medical staff. To meet the patient's needs and improve nurses' services, health departments in the home country should deliver better medical packages, higher salaries, equipment 
accessibility, and stringent supervision. It is essential to create health sector policies that will enforce higher standards of safety and security should be maintained in hospitals. Moreover, an useful public and private partnership approach could be developed and implemented in Bangladesh to augment the government's effort in improving countless services in hospitals such as pharmacies near hospitals, proper management of all schedules to avoid misbehavior, Moreover, hotels and restaurants of international customary near hospitals, airports pick-up and drop-up services need to be upgraded to attract more domestic medical tourists which would help the country earn valuable foreign exchanges.

By implementation these recommendations, Bangladesh could rapidly improve the quality of medical care in the country. This would help reduce outbound medical tourism from Bangladesh significantly, which will generate a vast earning for the country. From the study we have found empirical evidence that people who travel for getting health care to India, Thailand and Singapore gets better satisfaction and quality services. The findings indicated that, all of the research findings would assist relevant stakeholders of healthcare industries to formulate and implement effective strategies in order to attract and retain outbound medical tourists in Bangladesh

\section{IMPLICATION FOR FUTURE RESEARCH}

Future studies can be carried out to further investigate these areas:

i. The study has been conducted to examine the views of only outbound medical tourists. Hence, future researches can be directed to explore the views of both inbound and outbound medical tourists.

ii. The study was done based on 300 respondents only. If the sample size of the study can be increased, then it will give more realistic findings and understanding of the reasons behind rise of outbound medical tourism from Bangladesh.

iii. Quality of care, access and affordability of healthcare in both public and private hospitals of Bangladesh should be explored in future studies. One of the areas which can be addressed in the future studies is that the research should be carried out in different parts of the country; so that the findings can be generalized.

\section{LIMITATIONS OF THE STUDY}

The study attempted to interview only outbound medical patients in Bangladesh. But other patients who seek treatment in the country and do not go outside, and attendants of the patients have not been captured in the study. Besides critical or very serious patients and non- curable patients were excluded from the study on ethical grounds and as advised by treating physicians.

\section{REFERENCES}

Abubakar, M.A., \& Ilkan, M. (2016). Impact of online WOM on destination trust and intention to travel: a medical tourism perspective. Journal of Destination Marketing \& Management, 5(3), 192-201. https://doi.org/10.1016/j.jdmm.2015.12.005

Ali, M.M., \& Medhekar, A. (2016). Globalization, medical travel and healthcare management in Bangladesh. Problems and Perspectives in Management, 14(2-2), 360-375. https://doi.org/10.21511/ppm.14(2-2).2016.12

Ali, M.M., \& Medhekar, A. (2018). Healthcare quality of bangladesh and outbound medical travel to Thailand. Ekonomika Regiona [Economy of Region], 14(2), 575-588. https://doi.org/10.17059/2018-2-19

Andaleeb, S.S. (1998). Determinants of customer satisfaction with hospitals: a managerial model. International Journal of Health Care Quality Assurance, 11, (6-7), 181-7. https://doi.org/10.1108/09526869810231541

Andaleeb, S.S., Siddiqui, N., \& Khandaker, S.A. (2007). Patient satisfaction with health services in Bangladesh. Health Policy and Planning, 22, 263-273. http://doi.org/10.11591/ijphs.v9i1.20386

Babić-Banaszak, A., Kovacić, L., Mastilica, M., Babić, S., Ivanković, D., \& Budak, A. (2001). The Croatian health survey--patient's satisfaction with medical service in primary health care in Croatia. Collegium Antropologicum, 25 (2), 449-458.

Bikker, A.P., \& Thompson, A.G.H. (2006). Predicting and comparing patient satisfaction in four different modes of health care across a nation. Social Science \& Medicine, 63, (6), 1671-1683. https://doi.org/10.1016/j.socscimed.2006.03.022

Biswas, C., Omar, H., \& Rashid-Radha, J.Z.R.R. (2020). The impact of tourist attractions and accessibility on tourists' satisfaction: The moderating role of tourists' age. GeoJournal of Tourism and Geosites, 32(4), 1202-1208. https://doi.org/ 10.30892/gtg.32402-558

Biswas, C., Omar, H.B., \& Rashid, J.Z.R.R.B. (2020). A conceptual framework of what influences tourist satisfaction in Bangladesh using HOLSAT model. Journal of Critical Reviews, 7(19), 8066-8072. https://doi.org/10.31838/jcr.07.19.910

Bookman, M. Z., \& Bookman K.R. (2007). Medical Tourism in Developing Countries, New York, Palgrave Macmillan.

Celik, A.K., Oktay, E., \& Akbaba, A.I. (2014). An ordered logit analysis of inpatient and outpatient satisfaction in a Turkish state hospital. Istanbul University Journal of the School of Business. 43(2), 237-250.

Chang, S.H., Yang, M.C., \& Chiang, T.L. (2003). Patient satisfaction with recommendation of a hospital: effects of interpersonal and technical aspects of hospital care. International Journal of Quality in Health Care, 15(4), 345-355. https://doi.org/10. 1016/j.socscimed.2006.03.022

Chen, C., \& Chen, F. (2010). Experience quality, perceived value, satisfaction and behavioral intentions for heritage tourists. Tourism Management, 31(1), 29-35. https://doi.org/10.1016/j.tourman.2009.02.008

Chen, H., Li, M., Wang, J., Xue, C., Ding, T., Nong, X., Liu, Y., \& Zhang, L. (2016). Factors influencing inpatients' satisfaction with hospitalization service in public hospitals in Shanghai, People's Republic of China. Patient Preference and Adherence, $10,469$. https://doi.org/ 10.2147/PPA.S98095

Chon, K. (1989). Understanding recreational travelers' motivation, attitude and satisfaction. The Tourist Review, 44(1), 3-7. https://doi.org/10.1108/eb058009

Collins, A., Medhekar, A., Wong, H., \& Cobanoglu, A. (2019). Factors influencing outbound medical travel from the USA. Tourism Review, 74, 463-479. https://doi.org/10.1108/TR-06-2018-0083

Cortez, N. (2008). Patients without borders: the emerging global market for patients and the evolution of modern health care. Indiana Law Journal, 83 (1), 71-132. 
Crooks, V.A., Snyder, J., Johnston, R., \& Kingsbury, P. (2010). What is known about the patient's experience of medical tourism? BMC Health Service Research, 10, 266.

Drinkert, A. (2015). Medical tourism: a post-travel study measuring the impact of push \& pull factors on the perceived quality of the medical tourism experience. Ph. D California State Polytechnic University.

Esiyok, B., Cakar, M., \& Kurtulmusoglu, F.B. (2016). The effect of cultural distance on medical tourism, Journal of Destination Management \& Marketing, 1-10. http://dx.doi.org/10.1016/j. jdmm.2016.03.001

Gill, H., \& Singh, N. (2011). Exploring the factors that affect the choice of destination for medical tourism. Journal of Service Science and Management, 04(03), 315-324. https://doi.org/10.4236/jssm.2011.43037

Hadian, M., Jabbari, A., Mousavi, S.H., \& Sheikhbardsiri, H. (2021). Medical tourism development: A systematic review of economic aspects. International Journal of Healthcare Management, 14(2), 576-582. https://doi.org/10.1080/20479700.2019.1677977

Hancock, D. (2006). The Complete Medical Tourist. London, John Blake, 25-23.

Hasan, A.A., Biswas, C., Roy, M., Akter, S., \& Kuri, B.C. (2020). The Applicability of Theory of Planned Behaviour to Predict Domestic Tourist Behavioural Intention: The Case of Bangladesh. GeoJournal of Tourism and Geosites, 31(3), 1019-1026. https://doi.org/10.30892/gtg.31313-536

Hart, C.W. (2007). Beating the market with customer satisfaction, Harvard. Business Review, 85(3), 30-32.

Herrick, D.M. (2007). Medical tourism: Global competition in health care. National Center for Policy Analysis (NCPA) Policy Report 304.

Heydari, M., Yousefi, M., Derakhshani, N., \& Khodayari-Zarnaq, R. (2019). Factors Affecting the Satisfaction of Medical Tourists: A Systematic Review. Health Scope, 8(3), e80359. https://doi.org/10.5812/jhealthscope.80359

Kavadas, V., Barham, C., \& Finch-Jones, M. (2004). Assessment of satisfaction with care after inpatient treatment for esophageal and gastric cancer. British Journal of Surgery, 91(6), 719-723.

Koermer, C.D. \& Kilbane, M. (2008). Physician sociality communication and its effect on patient satisfaction. Communication Quarterly, 56(1), 69-86.

Luo, X., \& Homburg, C. (2007). Neglected outcomes of customer satisfaction. Journal of Marketing, 71(2), $133-149$.

MacKian, S. (2003). A review of health seeking behaviour: problems and prospects. Health Systems Development Programme.

Mamun, M.Z., \& Andaleeb, S.S. (2013). Prospects and problems of medical tourism in Bangladesh. International Journal of Health Services, 43(1), 123-141. https://doi.org/10.2190/HS.43.1. i.

Mattoo, A., \& Rathindran, R. (2006). How health insurance inhibits trade in health care? Health Affairs (Millwood), 25(2), 358-368.

Musa, G., Thirumoorthi, T., \& Doshi, D. (2012). Travel behavior among inbound medical tourists in Kuala Lumpur. Current Issues in Tourism, 15(6), 525-543. https://doi.org/10.1080/13683500.2011.626847

Oliver, R.L. (1997). Satisfaction: A Behavioral Perspective on the Consumer. New York: Irwin/McGraw-Hill.

Paffhausen, A.L., Peguero, C., \& Roche-Villarreal, L. (2010). “Medical tourism: a survey”, United Nations Economic Commission for Latin America and the Caribbean, Washington, D.C.

Ratnasari, R.T., Gunawan, S., Pitchay, A.A., \& Mohd Salleh, M.C. (2021). Sustainable medical tourism: Investigating health-care travel in Indonesia and Malaysia. International Journal of Healthcare Management, 1-10. https://doi.org/10.1080/20479700.2020.1870365

Siddiqui, N., \& Khandaker, S.A. (2007). Comparison of Services of Public, Private and Foreign Hospitals from the Perspective of Bangladeshi Patients. J Health PopulNutr, 25(2), 221-230.

Smith, M., \& Puczko, L. (2009). Health and Wellness Tourism. Elsevier, USA, 1-10.

Stanley, M. (2010). Anywhere but Here. National Underwriter/Life \& Health Financial Services, 114 (18), 22-25.

Sultana, S., Haque, A., Momen, A., \& Yasmin, F. (2014). Factors affecting the attractiveness of medical tourism destination: an empirical study on India- Review Article. Iranian J Publ Health, 43(7), 867-876.

Snyder, J., Byambaa,T., Johnston,R., Crooks, V.A., Janes, C., \& Ewan, M. (2015). Outbound medical tourism from Mangolia: a qualitative examination of proposed domestic health system and policy responses to this trend. BMC Health Services Research, 15(187).

Tung, Y. \& Chang, G. (2009). Patient satisfaction with and recommendation of a primary care provider: associations of perceived quality and patient education. International Journal in Quality Health Care, 21(3), 206-213.

Zeithaml, V.A., \& Bitner, M.J. (2008). Services marketing. New York: McGraw-Hill.

*** Health Bulletin (2018). Bangladesh health situation. Government of The People's Republic of Bangladesh, Ministry of Health and Family Welfare Accessed on $20^{\text {th }}$ November, 2019. https://dghs.gov.bd/images/docs/Publicaations/HB\%202018\%20final.pdf

*** Medgadget (2021). Medical Tourism Market Size Worth \$274.37 Billion | Industry Statistics, Growth, Share, Current Trends and Research Development Report to 2027. https:/www.medgadget.com/2021/02/medical-tourism-market-size-worth-274-37-billion-industry-statisticsgrowth-share-current-trends-and-research-development-report-to-2027.html\#: :text=Global\%20Medical\%20Tourism\%20Market\% 20is, $12.8 \% 25 \% 20$ over\%20the\%20forecast\%20period.

*** The Business Standard (2020). Out-of-pocket health expenditure 74\%. Accessed on $17^{\text {th }}$ September 2020. https://tbsnews.net/ bangladesh/health/out-pocket-health-expenditure 7489572\#: :text=Out\%2Dof\%2Dpocket\%20expenditure\%20in,very\%20high\%20 at $\% 2074 \% 20$ percent.\&text $=\mathrm{He} \% 20$ mentioned $\% 20$ that $\% 20$ the $\% 20$ numberMalaysia\% 20and $\% 202.1 \% 20 \mathrm{in} \% 20$ Thailand

*** The Business Standard (2021). 54\% of medical tourists in India last year were from Bangladesh. Accessed on $15^{\text {th }}$ July, 2021. https://www.tbsnews.net/bangladesh/54-medical-tourists-india-last-year-were-bangladesh-278476

*** The Financial Express (2017). BD spends one-third of what who recommends. Accessed on $1^{\text {st }}$ September, 2019. https://www. thefinancialexpress. com.bd/economy/bangladesh/bd-spends-one-third-of-what-who-recommends-1513396554

*** The Straits Times (2015). Singapore 'losing medical tourists to neighbors'. Accessed on 20th November, 2018 .https://www. straitstimes.com/business/singapore-losing-medical-tourists-to-neighbours,

*** UNB (2020). Corona-hit health sector gets highest priority in budget with Tk29,247 allocation. Accessed on $15^{\text {th } J u l y, ~} 2020$. https://unb.com.bd/category/Bangladesh/corona-hit-health-sector-gets-highest-priority-in-budget-with-tk29247-allocation/52880 